\title{
Culture Unbound Vol. 9 Editorial
}

\author{
By Eva Hemmungs Wirtén, James Meese, Johanna Dahlin \& Kristin Wagrell
}

2017 promises to be an exciting year for Culture Unbound. We have four very interesting issues planned for volume 9 , and this year also marks the end of one of our projects and the start of another. In late 2016 we learned that Culture Unbound would receive funding from The Joint Committee for Nordic Research Councils in the Humanities and Social Sciences for 2017-2020. We are enormously grateful for this grant, as it secures the journal's Gold Open Access profile and ensures the absence of any author fees for the next few years. Our overall goal is to maintain an open, inclusive and truly interdisciplinary perspective across the journal while at the same time identifying and developing the distinctive tone, approach and choice of subjects that have emerged over the years since Culture Unbound was founded.

The editorial team has been expanded with the editorial assistant Kristin Wagrell. Eva Hemmungs Wirtén remains as editor in chief and is joined by James Meese as associate editor and Johanna Dahlin as executive editor. The editorial team members are based on different continents but are looking forward to convening in Norrköping to set out future directions for the journal. We would like to invite to our readers to take part in the improvement of Culture Unbound by suggesting changes, contributing articles and proposing thematic sections for the coming years. We will continue to embrace diversity, stay alert and keep our minds open to accommodate emerging fields of research.

Each of volume 9's planned issues contains a thematic section which promises creative and stimulating reading. Due to unforeseen circumstances the publication of our first issue was postponed from the spring to the autumn of 2017. This first issue contains the thematic section Theorizing Copies which departs from the notion of copying as a fundamental part of being human. Copying refers to cornucopia, the horn of plenty, and thus to abundance, fertility and life. On the other hand, however, copies and copying also refer to the lack of originality and authenticity, to dishonesty, forgery and fakeness. In an age of digitization and new media,

Hemmungs Wirtén, Eva, James Meese, Johanna Dahlin \& Kristin Wagrell: “Culture Unbound Vol. 9 Editorial”, Culture Unbound, Volume 9, issue 1, 2017: i-iii. Published by Linköping University Electronic Press: http://www.cultureunbound.ep.liu.se 
new theories and understandings of authenticity need to be developed. This thematic section argues that copies and copying practices are, and always have been, fundamental to the creation of authenticity, uniqueness and originality. Making copies means creating cultural value. The issue will present a selection of studies which all aim at investigating a field of cultural production where copying takes place and is - the authors argue - vital to how notions of value, authenticity and uniqueness are being created, negotiated and, at times, contested.

Issue 2 will contain the thematic section Spotify and Digital Methods. The section presents a collection of articles, which all offer a substantive account of emerging streaming cultures by analysing the music streaming service Spotify through an innovative methodological approach based on the reverse engineering of Spotify's algorithms, aggregation procedures, metadata, and valuation strategies. The thematic section provides a new perspective on Spotify as a platform and also stands as a major contribution to digital methods research.

Issue 3 will contain the thematic section Mediatization, Mobility and New Methods of Knowledge Production. This issue stems from the network The Everyday life of research in the medialisation era, of which Culture Unbound has been a part for the past two years. This network will hold its final workshop 'Publishing and mediatization' in Norrköping on June 21, 2017, and we are looking forward to this opportunity to discuss the role of scholarly publishing.

Issue 4 will contain the thematic section This Season of Discontent: Understanding Student Movements in Neoliberal Times, which aims at bringing together contributions from countries currently in the throes of student movements the world over; from Brazil to South Africa and India. Increasing repression of institutions of higher learning, and what is now commonly identified as the commercialisation of higher education, has led a wave of student protests. This thematic issue is an attempt to tackle the larger question of how we may, as scholars, educators and ethnographers, engage with and elucidate these student movements.

Together with Open Humanities Press, Culture Unbound has received a grant from The Seed Box, an international environmental humanities collaboration headquartered at Linköping University in Sweden, for a three-year project addressing the cultural impacts of climate change. The project is focused on new languages, forms and images of climate change through a series of "Living Lab" workshops; and aims to develop new practices of scholarly communication in the recognition that major environmental changes are placing new demands on existing forms of knowledge and dissemination. Year 1 is themed The Digital Rhetorics of Climate Change, and the lab "Mutating Epistimes" was held in Sydney at the University Technology of Sydney library in May 2017. The lab opened with a keynote from Lissa Holloway-Attaway from the University of Skövde. Researchers from Australia and Sweden then shared their research interests through a series of 
"lightning talks". These talks served as points of departure from which to consider what new forms of scholarly communication might look like. The project will progress through a number of forthcoming living labs.

Finally, we would like to end this editorial and open this volume by expressing our gratitude to the people that never get recognised for the crucial work they do for the journal: the anonymous reviewers. The referees are the core of academic publication and serve as an indispensable voice of expertise for the editor and a source of support and constructive critique for the authors. While they often contribute greatly to the outcome of the final publication, they are per definition always left out when credits are distributed.

Eva Hemmungs Wirtén is Editor-In-Chief for Culture Unbound. She is Professor of Mediated Culture at the Department of Culture Studies (Tema Q), Linköping University. She has written extensively on the cultural history of international copyright and the public domain. Her most recent book, Making Marie Curie: Intellectual Property and Celebrity Culture in an Age of Information was published by University of Chicago Press in 2015. In 2017, she was awarded an ERC Advanced Grant for the project "Patents as Scientific Information, 1895-2020," (PASSIM), which will run between 2017-2022. E-mail: eva.hemmungs.wirten@liu.se

James Meese is Associate Editor for Culture Unbound. He is Lecturer in Communication at the University of Technology Sydney. He researches information law and digital. His research has been published in Television and New Media, the International Journal of Communication, and the European Journal of Cultural Studies and he is currently writing a monograph on subjectivity in copyright law for MIT Press. E-mail: ames.meese@uts.edu.au

Johanna Dahlin is Executive Editor for Culture Unbound. She is post-doctoral fellow at Linköping University and Södertörn University. She is currently working in a research project concerned with how common resources are enclosed and privatised, focusing on the processes and relations involved in mineral extraction. E-mail: un@isak.liu.se

Kristin Wagrell is the new editorial assistant for Culture Unbound. She is a doctoral candidate in cultural studies at the Department for Studies of Social Change and Culture at Linköping University, and has a background in history and political theory. In her dissertation, Wagrell explores the position of Jewish Holocaust survivors in Swedish public and scientific discourse and the creation of national testimonial archives. For questions concerning Culture Unbound, contact her at:cu@isak.liu.se 